\title{
Does socioeconomic status influence oral cancer awareness? The role of public education
}

Somayyeh Azimi, ${ }^{1}$ Zahra Ghorbani, ${ }^{2}$ Erfan Ghasemi, ${ }^{3}$ Marc Tennant ${ }^{1}$ and Estie Kruger ${ }^{1}$

${ }^{1}$ International Research Collaborative, Oral Health and Equity, School of Human Sciences, University of Western Australia, Crawley, Australia. (Correspondence to: Somayyeh Azimi: somayyeh.azimi@uwa.edu.au). ${ }^{2}$ Community Oral Health Department, Dental School; ${ }^{3}$ Department of Biostatistics, School of Paramedical Sciences, Shahid Beheshti University of Medical Sciences, Tehran, Islamic Republic of Iran.

\begin{abstract}
Background: Public awareness on oral cancer is thought to improve prevention and early diagnosis; however, the role of socioeconomic status in this awareness is not clear.

Aims: The aim was to investigate whether an association exists between socioeconomic status and oral cancer awareness in adults.

Methods: A multi-stage random sample of adults was investigated in Tehran in 2016-2017. The outcome was awareness of oral cancer and knowledge of risk factors and signs and symptoms using a self-administered questionnaire. The main exposures were self-reported socioeconomic status of 8 indicators of family assets and economic situation. Wealth index was created using principal component analysis, and participants were classified into 5 quintiles. Regression analysis was applied to test associations.

Results: Out of 1800 adults, 1312 completed questionnaires were returned ( $72.8 \%$ response rate). The mean age was 37.8 (standard deviation 9.0) years; about 60\% were female. Statistical analysis revealed the higher the wealth index, the higher the score for oral cancer knowledge and awareness. Awareness and knowledge were significantly lower among participants in the poorest quintile: they had a knowledge score on oral cancer risk factors 1.58 points [95\% confidence interval (CI): -2.19;-0.96] lower, and a knowledge score on oral cancer signs 1.34 points (95 CI: -1.98;-0.72) lower compared with the richest quintile.
\end{abstract}

Conclusion: Socioeconomic inequalities were observed in oral cancer awareness in the Islamic Republic of Iran.

Keywords: socioeconomic status; principal components analysis; oral cancer; awareness

Citation: Azimi S; Ghorbani Z; Ghasemi E; Tennant M; Kruger E. Does socioeconomic status influence oral cancer awareness? The role of public education. East Mediterr Health J. 2020;26(12):1510-1517. https://doi.org/10.26719/emhj.20.060

Received: 04/09/18; accepted 29/12/20

Copyright (c) World Health Organization (WHO) 2020. Open Access. Some rights reserved. This work is available under the CC BY-NC-SA 3.0 IGO license (https://creativecommons.org/licenses/by-nc-sa/3.o/igo).

\section{Introduction}

The association between socioeconomic status (SES) and health outcomes has been widely documented in previous studies (1-5). Evidence of inequalities in oral health has been repeatedly illustrated between and within countries. Oral cancer, including cancer of the lip and oral cavity, is not an exception, and recent global data has shown differences in incidence and mortality in different countries (5-8). Global Cancer Incidence, Mortality and Prevalence (GLOBOCAN) estimated 354864 (2.0\% of all sites) new cases of lip and oral cavity cancer, and 177384 (1.9\% of all sites) deaths worldwide in 2018. Age-standardized lip and oral cavity cancer incidence among men and women in Western Aisa has been reported to be 2.1 and 1.1 per 100000 (8). However, country-specific incidence and mortality rates have not been documented in this Region $(7,9)$.

Associations between oral cancer risk and low SES (10), as well as the relationship between survival and mortality of oral cancer and both individual and area deprivation have been determined previously (11). Despite some theoretical explanations for the disparity in health, public health researchers still debate of how SES is a factor in impaired health $(1,5,12)$.

In patients of lower SES, first presentation with more-advanced stages of oral cancer has been proposed as a possible association with disparity in oral cancer burdens (13). Moreover, lack of or insufficient knowledge of oral cancer has been suggested as an effective factor in late diagnosis (13). Therefore, it could be proposed that socioeconomic positon has an effect on awareness and knowledge about oral cancer, and in turn advanced stage diagnosis.

Previous studies have used various indicators, single or combined, to measure SES, mostly focused on occupation, education and income (14-17). However, unavailable or unreliable results have been mentioned for income and occupation, especially in developing countries (18). Ghorbani et al. developed an asset-based SES index using principal component analysis (PCA) as a method for determining weights for the components of a wealth index from a set of variables; they explored oral health inequalities in the Iranian population and suggested that household assets could be a good indicator 
for assessment of "long-run" economic status (18).

There have been multiple studies assessing the levels of awareness and knowledge of symptoms and risk factors of oral cancer all over the world (19-21), however, most of them used sociodemographic measures such as age, sex and education as attributing factors. Also, a review of the literature found that studies reporting oral cancer awareness in the Islamic Republic of Iran are rare with inconsistent results about sociodemographic factors (22-25). To the best of our knowledge, there is no study associating wealth status and level of knowledge about oral cancer in a developing country. The aim of this study was to investigate the association between individual wealth (by determining SES) and its association with awareness about oral cancer in the Islamic Republic of Iran.

\section{Methods}

\section{Background}

This cross-sectional study is follow-up to an oral cancer knowledge study that was conducted in Tehran in 20162017 using self-administered questionnaires (26).

\section{Ethics}

The research project was approved by the ethics committee of Shahid Beheshti University of Medical Sciences. The purpose of the study was fully explained in the questionnaire and responses to questions was on a voluntary basis. All participants were assured of anonymity and confidentiality.

\section{Questionnaire}

The questionnaire assessed the awareness and knowledge of risk factors and symptoms of oral cancer as well as socioeconomic status. It included demographic questions (sex, age), 4 yes/no questions about oral cancer awareness (heard about cancer, non-communicable nature, early diagnosis and treatment); 15 questions about knowledge of risk factors (tobacco, alcohol, sunlight, diet, genetics, age and human papilloma virus) and 11 questions about signs and symptoms (ulcers, red or white patches, swelling, difficulty swallowing, discomfort, change in voice and weight loss) (26). Oral cancer knowledge questions were closed-ended positive and negative questions with yes/no/do not know options $(27,28)$. The questionnaire was designed by slightly modifying previous valid questionnaires considering the local cultural, environmental and language environment $(27,28)$. For assessment of SES, we used an 8-item composite wealth index by adapting the existing validated asset questions (18), including house ownership (own/rent); yes/no questions about having a car, personal computer, dishwasher, steam-cleaner (a device to clean surfaces) and microwave; and questions about income satisfaction (How satisfied are you with your current household income? Highly satisfied, satisfied, dissatisfied, highly dissatisfied) and financial management (Do you have the ability to manage expenditure with the available monthly income? can't make ends meet, manage to get by, have enough money plus some extra, money is not a problem) considering the previous studies $(27,29,30)$.

Before finalizing the questionnaire, a pilot study was conducted on a random sample of 60 patients attending a dental school clinic to ensure clarity and practicability of the questions $(\alpha=0.81)$. Eventually, the final Farsi language questionnaire we created fitted onto a doublesided plus one single A4 sheet stapled together. The purpose of the study and instructions were explained at the beginning of the questionnaire. It took approximately 15 minutes to complete the questionnaire.

\section{Sampling and participation}

In accordance with previous studies in the Islamic Republic of Iran in recent years (24), 16\% was considered the proportion of knowledgeable patients (with regard to risk factors of oral cancer) for the sampling formula, and we estimated that 1000 participants should be sufficient for the survey. Additional sampling was added in order to compensate for losses and refusals.

The study population comprised adults who were parents of public primary school students in Tehran. The sampling method used a multi-stage, stratified, random technique. First, from the 22 municipal regions in Tehran and according to geographic location, 4 regions were selected in the south, east, west, and north. Then, were randomly selected 1 or 2 schools from the school list in each region. In each school, a grade was randomly selected and the invitation letter sent to all the parents in that grade. The invitation letter was sent home with each student so both parents had the chance to see the letter.

\section{Study design}

A total of 1800 parents were invited to participate in this study, which was conducted in Tehran in 2016-2017. Those who agreed to participate were asked to sign the consent form.

Participants were requested to return the completed the questionnaires on the same day, without any time restrictions and to use their own knowledge, without seeking information from online resources. Illiterate persons, who were not able to write/read, were excluded due to the self-administered nature of questionnaire. A brochure containing information about oral and lip cancer was provided to all parents in the sampled schools after finishing the study. This brochure was approved by the panel expert of community oral health and oral medicine specialists in Shahid Beheshti University of Medical Sciences, Tehran.

\section{Outcome variables}

Awareness about oral cancer and knowledge of risk factors and signs and symptoms were collected using a numerical scale. Each correct answer was allocated a score of 1 ; incorrect answers, including "do not know" answers scored zero. The final scores for each participant were summed up separately: 0-4 for awareness, 0-15 for risk factor knowledge, and 0-11 for the signs and symptoms knowledge. 


\section{Explanatory variables}

The main explanatory variable was a composite wealth index as the proxy for SES; PCA was applied to indicator variables and the samples classified into 5 equal wealth quintiles, where the first quintile represented the poorest $20 \%$ of the sample.

\section{Covariates}

Age was recorded in date of birth and was categorised into groups of 25-35, 35-45, and > 45 years.

\section{Statistics}

We used PCA to develop the wealth index using STATA, version 11.1. Because the items included both binary and continuous variables, polychoric correlations were applied in the principal factor analysis correlation matrix. Then the SES classification into 5 quintiles was conducted via cluster analysis of the 8-item composite wealth using the data-driven approach. Descriptive and univariate analyses were used to explore the distribution of oral cancer knowledge and awareness using SPSS, version 22. Statistical tests, including ANOVA and post hoc tests and general linear regression were used for analysis of the level of knowledge and awareness among sociodemographic groups. $P<0.05$ was considered statistically significant in the survey.

\section{Results}

Out of 1800 adults invited, 1312 completed questionnaires were returned (72.8\% response rate). In total, $62 \%$ of par- ticipants were female and 38\% were male with the average age 37.8 [standard deviation (SD) 9.0] years.

Mean score for awareness was 1.09 (SD 1.60) (out of 4), for risk factors knowledge was 5.3 (SD 3.0) (out of 15), and for signs and symptoms, knowledge was 4.5 (SD 2.9) (out of 11). Analysis indicated that oral cancer awareness and knowledge of oral cancer signs or risk factors were not significantly different between age categories. Male participants had less knowledge of oral cancer signs and risk factors $(P<0.05)$, however awareness did not differ between males and females (Table 1).

Principal component analysis revealed a single component with an Eigen-value $>1$, covering $84 \%$ of variance (data not shown). All variables included in this factor had positive factor scores, and all were associated with higher socioeconomic status.

Table 1 also demonstrates the relationship between SES and level of knowledge and awareness. There was a statistically significant difference between level of awareness and knowledge of oral cancer risk factors and signs and symptoms in the different socioeconomic groups $(P<0.001)$. The post hoc test results showed the higher the wealth index, the higher the score for oral cancer knowledge and awareness.

Table 2 shows general linear model analysis. The level of the wealth index remained statistically significantly associated with knowledge and awareness of oral cancer, controlling for age and sex (Table 2). People from the poorest quintile had a knowledge score on oral cancer

\begin{tabular}{|c|c|c|c|c|}
\hline \multirow[t]{2}{*}{ Characteristic } & Frequency & General awareness & $\begin{array}{l}\text { Knowledge of risk } \\
\text { factors }\end{array}$ & $\begin{array}{l}\text { Knowledge of } \\
\text { signs }\end{array}$ \\
\hline & No. (\%) & Mean (SD) & Mean (SD) & Mean (SD) \\
\hline \multicolumn{5}{|l|}{ Sex } \\
\hline Male & $489(38.2$ & $1.60(1.09)$ & $4.90(2.92)$ & $4.21(2.96)$ \\
\hline Female & $788(61.7)$ & $1.64(1.01)$ & $5.60(3.00)$ & $4.70(2.88)$ \\
\hline$P$-value ${ }^{\mathrm{a}}$ & & 0562 & $<0.001$ & $<0.001$ \\
\hline \multicolumn{5}{|l|}{ Age (years) } \\
\hline $25-35$ & $318(28.2)$ & $1.60(1.07)$ & $5.26(3.00)$ & $4.38(2.88)$ \\
\hline $35-45$ & $644(57.1)$ & $1.68(1.1)$ & $5.44(3.08)$ & $4.68(2.99)$ \\
\hline$>45$ & $165(14.6)$ & $1.59(1.0)$ & $5.17(2.83)$ & $4.26(2.88)$ \\
\hline$P$-value ${ }^{b}$ & & 0.4 & 0.50 & 0.16 \\
\hline \multicolumn{5}{|c|}{ Socioeconomic status quintilec } \\
\hline 5 th & $204(17.5)$ & $1.92(1.12)$ & $6.23(2.82)$ & $5.09(2.98)$ \\
\hline 4th & $258(22.2)$ & $1.72(1.03)$ & $5.85(2.87)$ & $4.88(2.92)$ \\
\hline 3th & $207(17.8)$ & $1.72(1.07)$ & $5.45(3.05)$ & $4.60(3.01)$ \\
\hline 2nd & $262(22.5)$ & $1.54(1.07)$ & $4.95(2.95)$ & $4.35(2.83)$ \\
\hline 1st & $233(20.0)$ & $1.30(1.02)$ & $4.69(2.97)$ & $3.91(2.68)$ \\
\hline$P$-value ${ }^{b}$ & & $<0.001$ & $<0.001$ & $<0.001$ \\
\hline
\end{tabular}

SD = standard deviation.

${ }^{a}$ Independent samples t-test.

${ }^{b}$ Analysis of variance test.

${ }^{c} 1$ st $=$ poorest $;$ th $=$ richest. 


\begin{tabular}{|c|c|c|c|c|c|}
\hline \multirow[t]{2}{*}{ Knowledge/ awareness } & \multirow[t]{2}{*}{ SES $^{a}$} & \multirow[t]{2}{*}{$\mathbf{B}^{\mathbf{b}}$} & \multirow[t]{2}{*}{ P-value } & \multicolumn{2}{|c|}{$95 \%$ confidence interval } \\
\hline & & & & Lower bound & Upper bound \\
\hline \multirow[t]{5}{*}{ General awareness } & 1 st & -0.69 & $<0.001$ & -0.91 & -0.46 \\
\hline & 2nd & -0.45 & $<0.001$ & -0.67 & -0.22 \\
\hline & 3th & -0.27 & 0.02 & -0.50 & -0.04 \\
\hline & 4th & -0.23 & 0.03 & -0.45 & -0.01 \\
\hline & 5th & $\mathrm{R}$ & & & \\
\hline \multirow[t]{5}{*}{ Knowledge of risk factors } & 1st & -1.58 & $<0.001$ & -2.19 & -0.96 \\
\hline & 2nd & -1.43 & $<0.001$ & -2.04 & -0.82 \\
\hline & 3th & -0.84 & $<0.001$ & -1.48 & -0.21 \\
\hline & 4th & -0.39 & 0.20 & -0.99 & 0.21 \\
\hline & 5th & $\mathrm{R}$ & & & \\
\hline \multirow[t]{5}{*}{ Knowledge of signs } & 1st & -1.34 & $<0.001$ & -1.96 & -0.72 \\
\hline & 2nd & -0.83 & $<0.001$ & -1.44 & -0.22 \\
\hline & 3th & -0.59 & 0.06 & -1.22 & 0.03 \\
\hline & 4th & -0.32 & 0.28 & -0.93 & 0.27 \\
\hline & 5th & $\mathrm{R}$ & & & \\
\hline
\end{tabular}

All analyses adjusted for age and sex.

$\mathrm{R}=$ reference.

${ }^{a} 1 s t=$ poorest $;$ th $=$ richest .

${ }^{b}$ Coefficient estimate.

risk factors 1.58 points [95\% confidence interval (CI): -2.19;-0.96] lower, and a knowledge score on oral cancer signs 1.34 points $(95 \% \mathrm{CI}:-1.98 ;-0.72)$ lower compared with the richest quintile.

\section{Discussion}

This study is one of the first epidemiological studies on oral cancer awareness in the Islamic Republic of Iran, studying awareness of both risk factors and signs. Our findings indicate that oral cancer awareness is insufficient among the studied population, the mean scores for both risk factors and signs being around 30\% of the full scores. Mean general awareness score (1.09 out of 4) points to a lack of knowledge on oral cancer in adults. Details have been provided in previous studies $(26,31)$. Also, people in the lower SES quintiles had lower general awareness and less knowledge about risk factors and signs and symptoms of oral cancer.

In light of the difficulties in accessing the adult population to get a random sample, we tried to use public schools as the setting for sampling. Considering the random selection of schools from different geographic areas of the huge city of Tehran, it seemed to achieve a large sample of adults in a low-cost way. Compared to the whole adult population, parents are of special importance; an informed parent can affect the health of the whole family, including the next generation. However, the parent population is not a representative sample of the adult population, making our findings ungeneralizable to the whole adult population of Tehran. The lack of illiterate participants also affected generalizability. The results may, however, be generalizable to Iranian parents because the SES and education level is higher in Tehran than other urban and rural areas across the country.

Oral cancer, being a life-threatening disease, is usually diagnosed late. The survival rate may be improved significantly if the disease is diagnosed in the early stages or if the precancerous lesions are treated (32). Our findings showed that the level of awareness of oral cancer risk factors was low. This is a crucial issue in prevention of oral cancer as people do not even know which harmful behaviours and exposures may cause oral cancer. Awareness is the first step, and it is the primary step towards changing attitudes and performance in this regard. We found that the level of awareness of oral cancer signs was low as well. This lack of information may lead to late diagnosis, hence affecting survival rates. The low level of public awareness of oral cancer has also been reported by other researchers from different countries, which reveals the need for education all around the world $(16,21,33)$.

Another finding of this study was the lower awareness among people from the low-SES group, who may have limited access to knowledge sources about their health, including information on oral cancer. This may be because of their lower level of educational attainment, lower level of health literacy and public education, and less frequent physician/dental visits (34-36).

A number of studies have evaluated the association between sociodemographic indices such as age, sex, education, occupation and level of knowledge of oral cancer $(33,37)$. Different studies reported inconsistent results on the relationships between level of knowledge 
and sex and age. In the Islamic Republic of Iran, only Pakfetrat et al. reported significant differences in knowledge among people with different occupations (23). Occupation may not be a good indicator of SES due to the existence of income inequalities within an occupation, as well as high rates of women without formal jobs in developing countries. Tadbir et al., Pakfetrat et al., and Gholami et al. reported the higher the education level, the higher the score for oral cancer knowledge $(22,23,25)$. Although education is a good predictor of SES, it is not a sole indicator of it. Income has been used as an indicator of SES in oral cancer knowledge studies before (17,33). However, there are high non-response rates on items directly measuring income, especially in developing countries due to cultural factors $(18,38)$.

In neighbouring countries, Al-Maweri et al. in Riyadh reported dental patients with lower SES were significantly less aware about oral cancer and had much less knowledge of the signs and risk factors (39). Hassona et al. also reported people with lower SES in Jordan were less well informed about the signs and risk factors of oral cancer (40).

In a recent study in the United Kingdom, Kawecki et al., using the deprivation index, indicated lower knowledge of mouth cancer in the most deprived areas (41). These studies are in line with our study. However, the measurement of SES can be different in different populations.

An asset-based approach, collecting information on ownership of a range of durable assets, is an alternative to traditional monetary indicators such as consumption expenditure or income, for measuring SES $(1,5)$. Ghorbani et al. created an asset based wealth index for measuring oral health inequality in Tehran and demonstrated the low level of oral health in the poorest quintile (5). Also, Islami et al. in the north of the Islamic Republic of Iran constructed an asset-based wealth index for assessing SES and oesophageal cancer, and reported the protective effect of high wealth scores in the group with the highest wealth status (top 20\%) (38), which is in line with the current study.

In the present study, a wealth index has been developed using asset items, as well as 2 indirect monetary questions about financial management and income satisfaction. Previous studies have shown that people often refuse to discuss their income information with others, and it is treated as sensitive or confidential, however, income satisfaction questions dealt with the emotional self-evaluation of income considering past or current income, or standard income relative to one's own merits and qualifications. Miething, in a survey in Germany, argues that it could be an indicator of perceived inequality as well as a non-income-based exogenous measure of income inequality (29). Also, financial management as the self-rated ability to manage with the available monthly income has been used as a component of measuring SES in previous studies (30).
In the current study, we used PCA for weighting to construct a wealth index based on a previous study (5) and our results show the first component explained more than $80 \%$ of the original variables. The criteria for the selection of variables for PCA are not well defined, and the number of selected components is arbitrary (42). In an Iranian study, Ghorbani et al., used PCA methods for measuring socioeconomic inequalities. They used the first component factor scores with coverage of $34 \%$ of variance. Also, they classified the samples into 5 equal wealth quintiles, similar to this study (18). Krefis et al, in a study in Ghana, used PCA asset-based wealth index for SES assessment with $20 \%$ coverage of the first component, and argued that combined SES indicators using PCAs provides a quantification and classification of individual SES levels and enables the use of the resulting score for risk analyses (30).

Although a well-designed PCA analysis has been set up as a suitable tool for assigning weights to the indicators in this study, all information on asset measures are based on self-reports of the participants, and were not confirmed by direct observation, and this is considered a limitation. However, we asked questions about easily recalled ownership or appliances, which reduces the possibility of recall bias. In addition, prices are not taken into consideration in asset ownership, so, the appropriateness of the wealth index may differ between regions. However, most previous studies used this approach for construction of a wealth index $(18,43)$. Moreover, based on the multi-stage sampling design, it is desired to run a multi-level regression model in any future analysis of the present data.

Also, as a strength of this study, a brochure about oral cancer risk factors and sign and symptoms has been handed out in primary schools after the study, which can help parents as well as children acquire oral cancer-related knowledge, emphasizing the role of public education.

A recent study in India used a mobile app for oral cancer awareness in the general population. They argued that mobile technology is used by all socioeconomic groups and the app can be used as a tool for patient education about prevention and early detection of oral cancer (44).

\section{Conclusion}

The results of this study demonstrate the advantage of multiple variables rather than a single indicator of SES. The inverse association between combined indictors of SES and all components of oral cancer knowledge (general awareness, knowledge of risk factors and signs and symptoms) has been confirmed in the present study. Although improvement in SES is not achievable without changing the general economy, dental public health policy makers should conduct active educational programmes, especially for the most deprived parts of the population to reduce the gap in oral cancer burden. 
Funding: This project was supported by the Dental School of Shahid Beheshti University of Medical Sciences in Tehran. Dr Azimi acknowledges the support of the Australian Government through an Australian Govern- ment research training programme scholarship from the University of Western Australia.

Competing interests: None declared.

\section{Influence du statut socio-économique sur le niveau de sensibilisation au cancer de la cavité buccale et rôle de l'éducation du public}

\section{Résumé}

Contexte : La sensibilisation du public au cancer de la cavité buccale permettrait d'améliorer la prévention et le diagnostic précoce. On ignore cependant encore dans quelle mesure le statut socio-économique influence le niveau de sensibilisation.

Objectifs : La présente étude visait à déterminer l'existence d'un lien entre le statut socio-économique et le niveau de sensibilisation au cancer de la cavité buccale chez les adultes.

Méthodes : Un échantillon aléatoire à plusieurs degrés composé d'adultes a été analysé à Téhéran (République islamique d'Iran) en 2016-2017. Un questionnaire auto-administré a été distribué en vue d'évaluer le niveau de sensibilisation au cancer de la cavité buccale et la connaissance des facteurs de risque et des signes et symptômes. Pour évaluer le statut socio-économique, huit indicateurs portant sur le patrimoine familial et la situation économique ont été utilisés. Un indice de richesse a été créé en utilisant l'analyse en composantes principales et les participants ont été classés en cinq quintiles. Une analyse de régression a été appliquée aux associations de tests.

Résultats : Sur les 1800 adultes approchés, 1312 ont rempli et retourné le questionnaire (taux de réponse de 72,8 \%). L'âge moyen était de 37,8 ans (écart type 9,0) ; environ $60 \%$ des participants étaient des femmes. L'analyse statistique a révélé que plus l'indice de richesse est élevé, meilleur est le niveau de connaissance et de sensibilisation à l'égard du cancer de la cavité buccale. Le niveau de connaissance et de sensibilisation était significativement plus faible chez les participants appartenant au quintile le plus pauvre : ils ont obtenu un score de connaissance sur les facteurs de risque du cancer de la cavité buccale inférieur de 1,58 point [intervalle de confiance à $95 \%$ (IC) : -2,19;-0,96] et un score de connaissance sur les signes du cancer de la cavité buccale inférieur de 1,34 point (IC à $95:-1,98 ;-0,72$ ) par rapport au quintile le plus riche.

Conclusion : Le statut socio-économique a une influence sur le niveau de sensibilisation au cancer de la cavité buccale en République islamique d'Iran.

$$
\begin{aligned}
& \text { هل تؤثر الحالة الاجتهاعية الاقتصادية على الوعي بسرطان الفم؟ دور التثقيف العام } \\
& \text { سمية عظيمي، زهرة قرباني، عرفان قاسمي، مارك تينانت، إستي كروجر } \\
& \text { الخالاصة } \\
& \text { الخلفية: يُعتقَد أن الوعي العام بسرطان الفم يعزّز الوقاية والتشخيص المبكرَيْن، ومع ذلك، فإن دور الحالة الاجتهاعية الاقتصادية في هذا الوعي غير } \\
& \text { واضح. } \\
& \text { الأهداف: هدفت هذه الدر اسة إلى التحقّق مما إذا كان هناك ارتباط بين الحالة الاجتماعية الاقتصادية والوعي بسرطان الفم لدى البالغين. }
\end{aligned}
$$

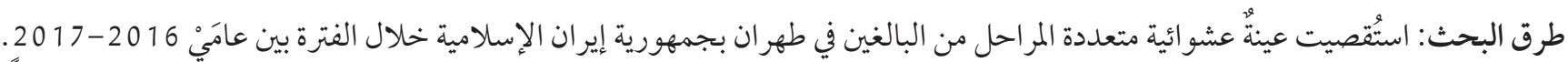

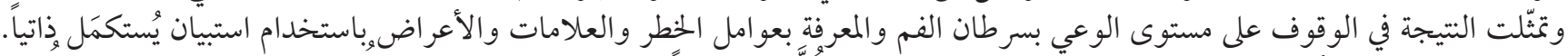

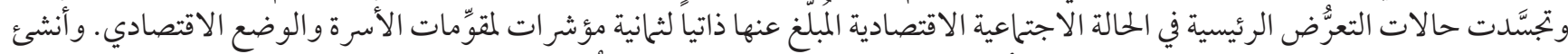

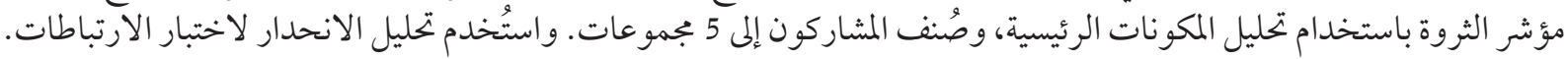

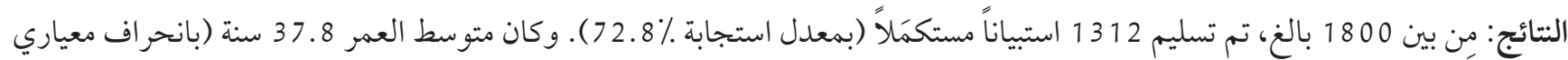

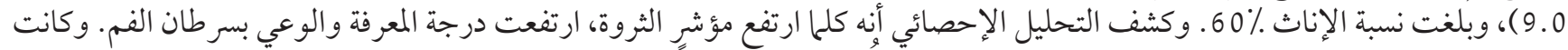

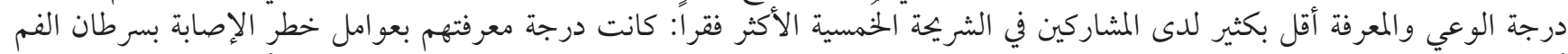

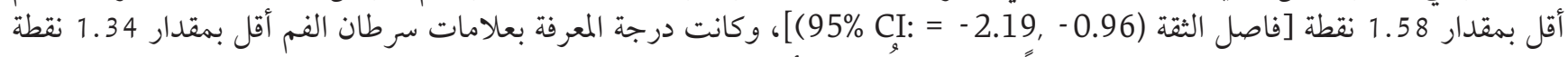

$$
\begin{aligned}
& \text { فاصل الثقة (95\% CI: = - 1.98, - 0.72) مقارنةً بالشريحة الخمسية الأكثر ثراءً. } \\
& \text { الاستناجات: لوحظت أوجه تفاوت اجتماعية اقتصادية في الوعي بسرطان الفم في جمهورية إيران الإسلامية. }
\end{aligned}
$$




\section{References}

1. Ghorbani Z, Peres KG. Is the association between socioeconomic status and nonreplaced extracted teeth mediated by dental care behaviours in adults? Commun Dentist Oral Epidemiol. 2015;43(6):532-9. doi:10.1111/cdoe.12178

2. Vathesatogkit P, Batty GD, Woodward M. Socioeconomic disadvantage and disease-specific mortality in Asia: systematic review with meta-analysis of population-based cohort studies. J Epidemiol Community Health. 2014;68(4):375-83. PMID:24407596

3. Steele J, Shen J, Tsakos G, Fuller E, Morris S, Watt R, et al. The interplay between socioeconomic inequalities and clinical oral health. J Dental Res. 2015;94(1):19-26. doi:10.1177/0022034514553978

4. Kumachev A, Trudeau ME, Chan KK. Associations among socioeconomic status, patterns of care, and outcomes in breast cancer patients in a universal health care system: Ontario's experience. Cancer. 2016;122(6):893-8. doi:10.1002/cncr.29838

5. Ghorbani Z, Ahmady AE, Ghasemi E, Zwi A. Socioeconomic inequalities in oral health among adults in Tehran, Iran. Community Dental Health. 2015;32(1):26-31. PMID:26263589

6. Azimi S, Mortazavi H, Tennant M, Kruger E, Rezaei B, Taheri JB, et al. Pattern of the head and the neck cancer in two geographically and socioeconomically different countries. J Orofacial Sci. 2017;9(1):43. doi:10.4103/0975-8844.207943

7. Ferlay J, Soerjomataram I, Dikshit R, Eser S, Mathers C, Rebelo M, et al. Cancer incidence and mortality worldwide: sources, methods and major patterns in GLOBOCAN 2012. Int J Cancer. 2015;136(5):E359-E86. doi:10.1002/ijc.29210

8. Bray F, Ferlay J, Soerjomataram I, Siegel RL, Torre LA, Jemal A. Global cancer statistics 2018: GLOBOCAN estimates of incidence and mortality worldwide for 36 cancers in 185 countries. CA. 2018;68(6):394-424. doi:10.3322/caac.21492

9. International Agency for Research on Cancer, Global Cancer Observatory. Cancer over time: Cancer mortality database. Geneva: World Health Organization; 2018. (http://www-dep.iarc.fr/WHOdb/WHOdb.htm, accessed 1 August 2019).

10. Warnakulasuriya S. Significant oral cancer risk associated with low socioeconomic status. Evid Based Dent. 2009;10(1):4-5. doi:10.1038/sj.ebd.6400623

11. Hagedoorn P, Vandenheede H, Vanthomme K, Willaert D, Gadeyne S. A cohort study into head and neck cancer mortality in Belgium (2001-11): are individual socioeconomic differences conditional on area deprivation? Oral Oncol. 2016 Oct;61:76-82. doi:10.1016/j.oraloncology.2016.08.014

12. Hafeman DM, Schwartz S. Opening the Black Box: a motivation for the assessment of mediation. Int J Epidemiol. 2009;38(3):838-45. doi:10.1093/ije/dyn372

13. Akram M, Siddiqui SA, Karimi AM. Patient related factors associated with delayed reporting in oral cavity and oropharyngeal cancer. Int J Preventive Med. 2014;5(7):915. PMID:25105006

14. Ganesh R, John J, Saravanan S. Socio demographic profile of oral cancer patients residing in Tamil Nadu-A hospital based study. Indian J Cancer. 2013 Jan-Mar;50(1):9-13. doi:10.4103/0019-509X

15. Dahlstrom KR, Bell D, Hanby D, Li G, Wang L-E, Wei Q, et al. Socioeconomic characteristics of patients with oropharyngeal carcinoma according to tumor HPV status, patient smoking status, and sexual behavior. Oral Oncol. 2015;51(9):832-8. doi:10.1016/j. oraloncology.2015.06.005

16. Al-Hakimi HA, Othman AE, Mohamed OG, Saied AM, Ahmed WA. Public knowledge of oral cancer and modelling of demographic background factors affecting this knowledge in Khartoum State, Sudan. Sultan Qaboos Univ Med J. 2016;16(3):e335. doi:10.18295/squmj.2016.16.03.012

17. Dost F, Do L, Farah CS. Knowledge of oral cancer risk factors amongst high $\square$ risk Australians: findings from the LESIONS programme. Aust Dent J. 2016;61(4):432-9. doi:10.1111/adj.12408

18. Ghorbani Z, Ahmady AE, Lando HA, Yazdani S, Amiri Z. Development of a socioeconomic status index to interpret inequalities in oral health in developing countries. Oral Health Prev Dent. 2013;11:9-15. doi:10.3290/j.ohpd.a29370

19. Ogundipe O, Ilesanmi O, Adegbulu A. Predictors of knowledge of risk factors of oral cancer among patients seeking dental treatment in a Nigerian tertiary institution. Dent Health Curr Res. 2015;2. doi:10.4172/2470-0886.1000104

20. Al-Maweri SA, Al-Soneidar WA, Dhaifullah E, Halboub ES, Tarakji B. Oral cancer: awareness and knowledge among dental patients in Riyadh. J Cancer Educ. 2017;32(2):308-13. doi:10.1007/s13187-015-0924-y

21. Formosa J, Jenner R, Nguyen-Thi M-D, Stephens C, Wilson C, Ariyawardana A. Awareness and knowledge of oral cancer and potentially malignant oral disorders among dental patients in far North Queensland, Australia. Asian Pac J Cancer Prev. 2015;16(10):4429-34. doi:10.7314/apjcp.2015.16.10.4429

22. Tadbir AA, Ebrahimi H, Pourshahidi S, Zeraatkar M. Evaluation of levels of knowledge about etiology and symptoms of oral cancer in southern Iran. Asian Pac J Cancer Prev. 2013;14(4):2217-20. doi:10.7314/apjcp.2013.14.4.2217

23. Pakfetrat A, Falaki F, Esmaily H, Shabestari S. Oral cancer knowledge among patients referred to Mashhad Dental School, Iran. Archi Iranian Med. 2010;13(6):543-8. doi:010136/AIM.0016

24. Razavi SM, Tahani B, Nouri S, Khazaei A. Oral cancer knowledge and practice among dental patients and their attitude towards tobacco cessation in Iran. Asian Pac J Cancer Prev. 2015;16:5439-44. doi:10.7314/apjcp.2015.16.13.5439

25. Gholami N, Mehrabi S, Zajkani E, Bashirinia G. Knowledge of adults about the symptoms and risk factors of oral cancer in Zanjan city. J Contemporary Med Sci. 2016;2(6):45-8. 
26. Azimi S, Ghorbani Z, Tennant M, Kruger E, Safiaghdam H, Rafieian N. Population survey of knowledge about oral cancer and related factors in the capital of Iran. J Cancer Educ. 2017:1-8. doi:10.1007/s13187-017-1275-7

27. Posorski E, Boyd L, Giblin LJ, Welch L. Oral cancer awareness among community-dwelling senior citizens in Illinois. J CommuniE ty Health. 2014 Dec;39(6):1109-16. doi:10.1007/s10900-014-9862-6

28. Dodd VJ, Riley I, Joseph L, Logan HL. Developing an oropharyngeal cancer (OPC) knowledge and behaviors survey. Am J Health Behav. 2012;36(5):589-601. doi:10.5993/AJHB.36.5.2

29. Miething A. A matter of perception: exploring the role of income satisfaction in the income-mortality relationship in German survey data 1995-2010. Social Sci Med. 2013;99:72-9.

30. Krefis AC, Schwarz NG, Nkrumah B, Acquah S, Loag W, Sarpong N, et al. Principal component analysis of socioeconomic factors and their association with malaria in children from the Ashanti Region, Ghana. Malaria J. 2010;9(1):201. doi:10.1186/1475-2875-9201

31. Azimi S, Ghorbani Z, Ghasemi E, Tennant M, Kruger E. Disparities in oral cancer awareness: a population survey in Tehran, Iran. J Cancer Educ. 2019 Jun;34(3):535-41. doi: 10.1007/s13187-018-1337-5.

32. Sargeran K1, Murtomaa H, Safavi SM, Teronen O. Delayed diagnosis of oral cancer in Iran: challenge for prevention. Oral Health Prev Dent. 2009;7(1):69-76. PMID:19408818

33. Hertrampf K, Wenz H-J, Koller M, Wiltfang J. Public awareness about prevention and early detection of oral cancer: a population-based study in Northern Germany. J Cranio-Maxillofacial Surg. 2012;40(3):e82-e6. PMID:21592808

34. Mantwill S, Monestel-Umaña S, Schulz PJ. The relationship between health literacy and health disparities: a systematic review. PLoS One. 2015 Dec 23;10(12):e0145455. doi:10.1371/journal.pone.0145455

35. Matsuyama RK, Wilson-Genderson M, Kuhn L, Moghanaki D, Vachhani H, Paasche-Orlow M. Education level, not health literacy, associated with information needs for patients with cancer. Patient Educ Couns. 2011;85(3):e229-e36. doi:10.1016/j. pec.2011.03.022

36. Hovick SR, Liang M-C, Kahlor L. Predicting cancer risk knowledge and information seeking: The role of social and cognitive factors. Health Commun. 2014;29(7):656-68. doi:10.1080/10410236.2012.763204

37. Elango JK, Sundaram KR, Gangadharan P, Subhas P, Peter S, Pulayath C, et al. Factors affecting oral cancer awareness in a highrisk population in India. Asian Pac J Cancer Prev. 2009;10(4):627-30. PMID:19827883

38. Islami F, Kamangar F, Nasrollahzadeh D, Aghcheli K, Sotoudeh M, Abedi-Ardekani B, et al. Socio-economic status and oesophageal cancer: results from a population-based case-control study in a high-risk area. International journal of epidemiology. 2009;38(4):978-88. doi:10.1093/ije/dyp195

39. Al-Maweri SA, Al-Soneidar WA, Dhaifullah E, Halboub ES, Tarakji B. Oral cancer: awareness and knowledge among dental patients in Riyadh. J Cancer Educ. 2017 Jun;32(2):308-13. doi:10.1007/s13187-015-0924-y

40. Hassona Y, Scully C, Abu Ghosh M, Khoury Z, Jarrar S, Sawair F. Mouth cancer awareness and beliefs among dental patients. Int Dent J. 2015 Feb;65(1):15-21. doi:10.1111/idj.12140

41. Kawecki MM, Nedeva IR, Iloya J, Macfarlane TV. Mouth cancer awareness in general population: results from Grampian Region of Scotland, United Kingdom. J Oral Maxillofac Res. 2019 Jun 30;10(2):e3. doi:10.5037/jomr.2019.10203

42. Howe LD, Hargreaves JR, Huttly SR. Issues in the construction of wealth indices for the measurement of socio-economic position in low-income countries. Emerging themes in epidemiology. 2008;5(1):3. doi:10.1186/1742-7622-5-3

43. Homenauth E, Kajeguka D, Kulkarni MA. Principal component analysis of socioeconomic factors and their association with malaria and arbovirus risk in Tanzania: a sensitivity analysis. J Epidemiol Community Health. 2017 Nov;71(11):1046-1051. doi:10.1136/ jech-2017-209119

44. Deshpande S, Radke U, Karemore T, Mohril R, Rawlani S, Ingole P. A novel mobile app for oral cancer awareness amongst general population: development, implementation, and evaluation. J Contemp Dent Pract. 2019 Feb 1;20(2):190-196. PMID:31058634 